\title{
The Effect of Incorporating Industrial Wastewater on Durabil- ity and Long Term Strength of Concrete
}

\author{
Ehsan Nasseralshariati ${ }^{1}$, Danial Mohammadzadeh ${ }^{1}$, Nader Karballaeezadeh ${ }^{1}$ and Amir Mosavi ${ }^{2, *}$ \\ 1 Faculty of Engineering, Department of Civil Engineering, University of Ottawa, K1N 6N5 Ottawa, Canada; \\ Enase063@uottawa.ca (E.N.); Danial.mohammadzadehshadmehri@mail.um.ac.ir (D.M.S.); \\ N.karballaeezadeh@shahroodut.ac.ir (N.K.) \\ 2 Building Materials and Construction Chemistry, TU Dresden, Dresden, Germany; \\ * Correspondence: amir.mosavi@mailbox.tudresden.de (A.M.)
}

\begin{abstract}
Concrete, as one of the essential construction materials is responsible for a vast amount of emissions. Using recycled materials and gray water can considerably contribute to the sustainability aspect of concrete production. Thus, finding a proper replacement for fresh water, in the production of concrete, is significant. The usage of industrial wastewater, instead of water in the concrete can be considered in this paper. In this study, 450 concrete samples are produced with different amounts of wastewater. The mechanical parameters such as slump, compressive strength, water absorption, tensile strength, electrical resistivity, rapid freezing, half-cell potential, and appearance are investigated. The results showed that the usage of industrial wastewater does not significantly change the main characteristics of concrete. Although, increasing the concentration of the wastewater can decrease durability and strength features nonlinearly.
\end{abstract}

Keywords: sustainable concrete; wastewater; industrial waste management; sustainable development; sustainable construction materials

\section{Introduction}

In the modern era, concrete is one of the most used materials in the construction industry [1-4]. Since the first-time concrete was utilized as the building material, the fresh water is used to produce and cure the concrete [5]. The performance of the concrete, which is made of wastewater had also been investigated, however, further researches are essential to examine whether using wastewater is financially resealable and could meet construction standards or not [6]. Clearly, there is still a research gap on life cycle assessment and further environmental, functional, and economic aspects of using wastewater [7]. Bearing in mind the amount of required water for construction projects, if potable water could be substituted by recycled water, it would reduce the costs, but it would also prevent wasting of an enormous amount of drinkable water resources [8]. Rivers and fountains which are not contaminated by domestic wastewaters and do not have a salty taste, are appropriate for concrete mix designs [9]. Researches also have indicated that the water of the lakes, which contain less Silt, organic materials, and impurities, has insignificant adverse effects on concrete features; however, other comprehensive studies are needed about other replacements [10]. In industrial and urban areas with limited drinkable resources and according to fast enhancement in industry, the demand for storing water is being felt more and more [11]. According to the majority of scientists, the best way to make construction materials is using the residue of materials, and one of the most prominent construction materials is concrete, which is used approximately 5 million cubic meters per year in the whole world [11]. This significant value can be counted as an excellent opportunity to use wastewater in concrete, containing $28 \%$ of the water cycle [12]. It is undeniable that one of the most usable basic materials in industrial towns is water, which becomes wastewater after using, and it is highly harmful to human health and the environment. Concerning the potable water crisis, especially in the Middle East, finding other water resources as a suitable replacement rather than drinkable water for producing and curing concrete has drawn significant attention, remarkably those 
solutions that not only economize cost and energy but also present novel methods. As a result, burring the harmful materials as well as better productivity are obtainable, and less detriment influences on the environment is expected. According to the United Nation (UN) world water development report, a series of global actions have been doing over five years, and it has costed over 25 billion dollars in order to have healthy infrastructures for water and wastewater [12]. It is worth mentioning that the amount of produced industrial wastewater and sludge in the United States of America are 119 billion gallons and 17 million tons per year, respectively; these statistics for Europe are 123 billion gallons and 18.9 million tons, respectively [12]. Therefore, according to the huge volume of industrial wastewater and its harmful effects on the environment, current study is urgently required. In this research, a help is provided to to find the level of wastewater refienemnet to be used in concrete producing. This can help to keep the wastewater infrastructures well maintained due to massive amount of caustic materials in industrial wastewater. Likewise, it defines a the amount of impurity a sample which can cause less than $10 \%$ compressive strength loss compared with the control sample, which is a crucial factor because it can approve using the different wastewater as an appropriate replacement for drinkable water.

Al-Ghusain and et al. [13] reported primary, secondary and tertiary treated wastewater was taken from the local wastewater plant. The water utilized by them did not change the slump; however, setting time was more increased by worsening water quality. They described that impurity in the water of concrete imposes different effects on setting time, strength and making some stains on the external surface. All impurities do not harm concrete and some reactions can be neutral or even suitable for concrete.

Shekarchi [14], carried out the use of biologically treated wastewater in concrete mixing and curing. Physical and mechanical tests were performed on mortar and concrete cube specimens. Some durability tests of concrete were also evaluated. When mixing and curing of concrete was done in primary and secondary water, the compressive strength increased up to $17 \%$ than concrete mixed and cured in tap water up-to 180 days. After 180 days a small reduction in concrete was observed which is mixed and cured in primary treated water and when secondary treated water was used as mixing or curing in concrete, compressive strengths were decreases from 9 to $18 \%$. The water absorption of the concrete mixed in tap water and treated wastewater was identical. Curing in secondary wastewater increased water absorption of the specimen. These results showed the feasibility of biologically treated water in the concrete production industry

Asadollahfardi et al. [15] studied using concrete wash water to produce concrete. Their results indicated that concrete wash water is suitable for producing fresh concrete. This research is based compressive strength, flexural strength, abrasion resistance, chloride resistance and carbonation resistance of treated wastewater concrete $(10 \%, 25 \%, 50 \%$ and $100 \%$ replacement with Tap water) and compares the results with control concrete. This research gives the feasibility of use of treated wastewater in concrete to reduce consumption of fresh water in concrete industry as well as to solve the disposal problem of the industrial wastewater

Asadollahfardi et al. [16] used the treated domestic wastewater instead of drinking water to produce and cure concrete samples. Their results indicated that the compressive strength of the samples made with treated domestic waste-water at the age of 28 days was $93-96 \%$ of the compressive strength of the control samples which made with drinking water. Also, the use of treated domestic wastewater did not have much effect (less than $4 \%$ decrease in resistance) on the tensile strength of the concrete samples; however, delayed the final setting time of cement by 15 min was observed.

Clearly, there is still a research gap in the functional and economical aspects of using wastewater. Due to develpomment in all industrial sectors which has flourished and enlargened the industrial towns as well as increasing the human population, coupled with the demand to curb expenditure in different government budget sectors, attention should be focused on the reuse of resources if possible. In the present research, different industrial wastewater concentrations were used for producing concrete specimens. Sub- 
sequently, the durability and strength within 365 days were assessed. For this purpose, two types of industrial wastewater were used. First, treated wastewater itself and its different concentrations including diluted and concentrated treated wastewater. Second, Primary Wastewater that is non-refined; it can reveal the quality of refineries' performance and the optimum extent of refinement for concrete.

\section{Materials and Methods}

\subsection{Method of Examination}

The used wastewaters are gathered from Toos industrial town, Mashhad, Iran, and within a maximum of three hours, wastewaters were analyzed in the laboratory. The analyses were done on industrial's primary wastewater, treated wastewater, diluted treated wastewater and concentrated treated wastewaters; the control specimen was produced with drinkable water of Mashhad City which is standard water. Altogether, 430 specimens were made in ten times pouring concrete and fourteen skilled operators participated in producing specimens, which took two hours in total. The number of done tests on specimens are as follows: slump 10 samples, compressive strength 240 samples, electrical resistivity 20 samples, water absorption of thirty minutes 10 samples, mass water absorption 10 samples, capillary water absorption 30 samples, tensile strength 40 samples, rapid freezing and thawing 40 samples and half-cell 30 samples. All of the tables, results, and tests are done exclusively for this research, and no archive data is used. Technical and Vocational University (TVU), Mashhad, Iran, provided researchers with test facilities. The used standards are shown in Table 1.

Table 1. The types of testing and the corresponding Standards

\begin{tabular}{lc}
\hline \multicolumn{1}{c}{ Type of testing } & Method of testing \\
\hline Chemical and physical properties of treated wastewater & APHA [17] \\
Mixing water for concrete. Specification for sampling, testing and assessing the suitability of & BS EN 1008 [18] \\
water, including water recovered from processes in the concrete industry, as mixing water for & ASTM-C150 [19] \\
concrete & ASTM C188-15 [20] \\
Standard specification for Portland cement & ASTM-C136 [21] \\
Standard test method for density of hydraulic cement & ASTM-C33 [22] \\
Standard test method for sieve analysis of fine and coarse aggregates & ASTM-C191 [23] \\
Standard specifications of concrete aggregates & ASTM C143 [24] \\
Standard test methods for time of setting of hydraulic cement by Vicat needle & BS 1881-116 [25] \\
Slump of hydraulic-cement concrete & ASTM-C496 [26] \\
Method for determination of compressive strength of concrete cubes & BS1881-122 [27] \\
Standard test method for splitting tensile strength of cylindrical concrete & FM-5-578 [28] \\
Absorption of concrete water & ASTM-C1585 [29] \\
Florida method of test For Concrete resistivity as an electrical indicator of & ASTM-666 [30] \\
its permeability & ASTM- C876-91 [31] \\
Water absorption rate by hydraulic- cement concretes & ASTM C642-13 [32] \\
Concrete resistance against thawing and rapid freezing & ASTM C231/M17a [33] \\
Standard method for test of half-cell potentials of uncoated reinforcing steel & \\
Standard test method for air content of freshly mixed concrete by the pressure method &
\end{tabular}

In this research, ten different groups of specimens were produced with different wastewater concentrations. All groups of specimens had the same mix design, and no additive was used in order to figure out the exact effect of wastewater concentration on concrete durability and strength features. In this study, one of the targets is to find the optimum concentration of treated wastewater which may cause less than $10 \%$ compressive strength loss compared with the control sample (made with drinkable standard water). Technically, 10\% compressive strength reduction still be counted as an acceptable substitution for water of concrete mix design [34]. The main control sample was made by 
the potable water of Mashhad city (Ctrl). The used industrial wastewaters are categorized into four groups. First, treated wastewater (TWW). Second, diluted treated wastewater which is a mixture with distilled water including $(75 \% \mathrm{TW}),(50 \% \mathrm{TW})$ and (25\%TW); numbers show the percentage of treated wastewater in the water mixture design. Third, concentrated treated wastewater which are the concentrated version of TWW, including $(\mathrm{TW}+20 \% \mathrm{C}),(\mathrm{TW}+25 \% \mathrm{C}),(\mathrm{TW}+30 \% \mathrm{C})(\mathrm{TW}+35 \% \mathrm{C})$; number shows the percentage of concentration. Fourth, Primary Wastewater (PWW) which is totally unrefined.

In addition, all groups of concrete specimens were produced in a similar situation and cured in drinkable water, treated wastewater according to the tests standards and intended purposes. Also, the parameters like concrete density, temperature, moisture, cement type, aggregates characteristics were used in the same condition for all of the specimens.

\subsection{Wastewaters}

For producing concrete with wastewaters, the amount of their distilled water based on the quality of the control specimen was considered and all other extra substances were subtracted. In majority of time, there is an allowable limit for the water of mix design that within those restrictions, the impurity can be harmless and acceptable. Nevertheless, there is no limitation for organic materials in concrete and it assumes that only wastewater impurities are the reasons for negative effects on water of concrete mix design.

\subsubsection{Treated Wastewater (TWW)}

Treated wastewater is known for output wastewater too and goes through three steps of refinement including filters, aeration and chlorination. Treated wastewater was used as the main replacement for drinkable water and it utilized for producing distilled and concentrated specimens as well. TWW was used for curing the specimens if they were intended to be cured by wastewater separately. The characteristics of TWW is presented in Table 2.

\subsubsection{Diluted Treated Wastewater (\%TW)}

Diluted specimens were produced by TWW plus mixing distilled water. They contained $75 \%$ wastewater $(75 \% \mathrm{TW}), 50 \%$ wastewater $(50 \% \mathrm{TW})$ and $25 \%$ wastewater $(25 \% \mathrm{TW})$ and the rest of percentages are distilled water. These water of mix designs were selected in order to investigate existence of linear or non-linear relationships in strength and durability features by diluting treated wastewater as the water of mix design. Based on the laboratory results, the number of parameters was reduced correctly by dilution percentages. In order to get the number of parameters in diluted specimens, the characteristics of treated wastewater (Table 2) should be reduced by dilution percentages.

\subsubsection{Concentrated Treated Wastewater (TW+ \%C)}

Concentrated specimens were produced from TWW by evaporation; concentrating percentages are $20 \%(\mathrm{TW}+20 \% \mathrm{C}), 25 \%(\mathrm{TW}+25 \% \mathrm{C}), 30 \%(\mathrm{TW}+30 \% \mathrm{C})$, and $35 \%$ $(\mathrm{TW}+35 \% \mathrm{C})$, respectively. Based on laboratory results, the parameters of thickened specimens were increased almost by concentration percentages. So, concentrated specimens have the same parameters of treated wastewater (Table 2) but their characteristics are $20 \%, 25 \%, 30 \%$, and $35 \%$ more than characteristics of Treated wastewater, respectively. According to the intended concentration, the amount of surplus treated wastewater was added and after measured time with precise warming temperature, intended concentration were achieved. However, reaching intended concentration by evaporation is almost acceptable but the sufficient accuracy for important parameters like COD, BOD, Sulfate, Chromium, Cadmium, and Salt were considered and double checked.

\subsubsection{Primary wastewater (PWW)}

The initial discharge of industrial wastewater is primary wastewater which is a collection of several polluting industries like pharmacy, food, Ironmaking and chemical. It 
contains lots of organic materials and caustic heavy metals like Cadmium and Chromium because it doesn't go through any refinement process and technically this is the TWW before refinement procedure. PWW has a huge amount of organic materials, microorganisms, and heavy metals which are mostly harmful and caustic for environment and concrete. Table 2 shows the characteristics of primary wastewater (PWW).

Table 2. Chemical and physical characteristics of treated wastewater and primary wastewater.

\begin{tabular}{cccccc}
\hline No. & Parameter & Unit & $\begin{array}{c}\text { Treated } \\
\text { wastewater }\end{array}$ & $\begin{array}{c}\text { Primary } \\
\text { wastewater }\end{array}$ & $\begin{array}{c}\text { Mashhad pota- } \\
\text { ble water (Ctr) }\end{array}$ \\
\hline 1 & pH & - & 7.92 & 7.68 & 7.2 \\
2 & Total dissolved solid & $\mathrm{Mg} / 1$ & 1870 & 2541 & 412 \\
3 & SALT & $\mathrm{Mg} / 1$ & 2.4 & 2.51 & 40 \\
4 & $\mathrm{EC}$ & $\mathrm{Mg} / 1$ & 3950 & 4120 & 193 \\
5 & $\mathrm{COD}$ & $\mathrm{Mg} / 1$ & 150 & 3215 & 0 \\
6 & $\mathrm{BOD}$ & $\mathrm{Mg} / 1$ & 114 & 1240 & 3 \\
7 & $\mathrm{TSS}$ & $\mathrm{Mg} / 1$ & 25 & 451 & 121 \\
8 & $\mathrm{Mg} / \mathrm{l}$ & 2 & 3 & 0.4 \\
9 & Detergent & $\mathrm{Mg} / 1$ & 1.25 & 3.1 & - \\
10 & Color & - & Light brown & Black & Transparent \\
11 & Temperature & ${ }^{\circ} \mathrm{C}$ & 17 & $17-19$ & 25 \\
12 & Sulfate & $\mathrm{Mg} / 1$ & 80 & 145 & 50 \\
13 & Chloride & $\mathrm{Mg} / 1$ & 1230 & 740 & 94 \\
14 & Chromium & $\mathrm{Mg} / 1$ & 0.9 & 1.89 & 0.1 \\
15 & Cadmium & $\mathrm{Mg} / 1$ & 0.7 & 2.95 & - \\
16 & Lead & $\mathrm{Mg} / 1$ & 2.85 & 2.85 & 0.02 \\
17 & Turbidity & Nephelometric & 10 & 800 & 2 \\
\hline
\end{tabular}

\subsection{Concrete Preparation}

For producing the control sample and curing all groups with normal water, portable water of Mashhad, Iran, was used. Also, the Portland cement type II was chosen and its quality was tested according to the ASTM-C150. Table 3 shows the chemical and physical properties of cement. For reducing the effect of other parameters on concrete, except wastewater, the good-quality, continuous, less flaw aggregate was used. The ASTM-C33 standard was adopted to test the characteristics of aggregates. It should be noted that the aggregates used in this study are kept in SSD condition. Mix design for all groups of specimens was the same and the concrete mixture is presented in Table 4. Likewise, the concrete specimens were molded in metal molds and cured based on ASTM-C31 [37]. The specimens were cured by drinkable water, treated wastewater. In addition, all requirements were done in term of curing and the storage of test specimens before rupture based on ASTM-C31. The concrete mixture is presented in Table 4.

For reaching the optimum mix design, ACI method of concrete mix design was used based on the water-cement ratio of 0.42 , and for mechanical mixing of the cement ASTM-C305 [36] was deemed. Also, the good-quality and washed aggregates were selected after several initial samples according to the details in Table 5.

Table 3. Chemical and physical properties of cement.

\begin{tabular}{|c|c|c|c|c|c|}
\hline Chemical \& Physical Measurands & Units & Test Method & ISIRI 389 & EN 197-1: 2011 & Sample Analysis \\
\hline $\mathrm{SiO}_{2}$ & $\%$ & $\begin{array}{c}\text { ASTM } \\
\text { C114:2011b }\end{array}$ & $>20.00$ & 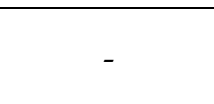 & 21.77 \\
\hline $\mathrm{Al}_{2} \mathrm{O}_{3}$ & $\%$ & $\begin{array}{c}\text { ASTM } \\
\text { C114:2011b }\end{array}$ & $<6.00$ & - & 5 \\
\hline $\mathrm{Fe}_{2} \mathrm{O}_{3}$ & $\%$ & ASTM & $<6.00$ & - & 4.3 \\
\hline
\end{tabular}




\begin{tabular}{|c|c|c|c|c|c|}
\hline \multicolumn{6}{|c|}{ C114:2011b } \\
\hline $\mathrm{CaO}$ & $\%$ & $\begin{array}{c}\text { ASTM } \\
\text { C114:2011b }\end{array}$ & - & - & 63.13 \\
\hline $\mathrm{MgO}$ & $\%$ & $\begin{array}{c}\text { ASTM } \\
\text { C114:2011b }\end{array}$ & $<5.00$ & $<5.00$ & 1.78 \\
\hline L.I.O & $\%$ & EN 196-2:2013 & $<3.00$ & $<5.00$ & 1.38 \\
\hline $\mathrm{SO}_{3}$ & $\%$ & EN 196-2:2013 & $<3.00$ & $<3.5$ & 2.22 \\
\hline IR & $\%$ & EN 196-2:2013 & - & $<5.00$ & 0.63 \\
\hline $\mathrm{Na}_{2} \mathrm{O}$ & $\%$ & EN 196-2:2013 & - & - & 0.32 \\
\hline $\mathrm{K}_{2} \mathrm{O}$ & $\%$ & EN 196-2:2013 & - & - & 0.83 \\
\hline $\mathrm{CI}$ & $\%$ & EN 196-2:2013 & - & $<0.10$ & 0.010 \\
\hline Free $\mathrm{CaO}$ & $\%$ & EN 196-2:2013 & - & - & 1.10 \\
\hline $\mathrm{Cao} / \mathrm{SIO}_{2}$ & - & & - & $>2.0$ & 2.90 \\
\hline $\mathrm{C}_{3} \mathrm{~S}+\mathrm{C}_{2} \mathrm{~S}$ & $\%$ & & - & $>66.667$ & 73.48 \\
\hline Fineness & $\mathrm{Cm}^{2} / \mathrm{gr}$ & & $>2800$ & - & 3000 \\
\hline Le Chatelier Expansion & $\mathrm{mm}$ & EN 196-3:2005 & - & $<10.00$ & 0.9 \\
\hline Initial Setting Time & $\min$ & EN 196-3:2005 & $>45$ & $>75$ & 116 \\
\hline Final Setting Time & $\min$ & EN 196-3:2005 & $<360$ & - & 175 \\
\hline 3 days Com. Strength & $\mathrm{MPa}$ & EN 196-3:2005 & - & - & 16.8 \\
\hline 7 days Com. Strength & $\mathrm{MPa}$ & EN 196-3:2005 & - & - & 23.2 \\
\hline 28 days Com. Strength & $\mathrm{MPa}$ & EN 196-3:2005 & - & $>32.5,<52.5$ & 45.3 \\
\hline
\end{tabular}

Table 4. The detail of concrete mixture designs

\begin{tabular}{|c|c|c|c|c|}
\hline Sample & Free water mass & Wastewater mass & Cement mass & Sand mass \\
\hline Control ( Ctrl) & $168 \mathrm{~kg}$ & - & $400 \mathrm{~kg}$ & $974 \mathrm{Kg}$ \\
\hline Treated wastewater (TWW) & - & $168 \mathrm{~kg}$ & $400 \mathrm{~kg}$ & $974 \mathrm{Kg}$ \\
\hline $\begin{array}{l}\text { Concentrated treated wastewater } \\
\qquad(\mathrm{TW}+\% \mathrm{C})\end{array}$ & - & $168 \mathrm{~kg}$ & $400 \mathrm{~kg}$ & $974 \mathrm{Kg}$ \\
\hline $\begin{array}{l}\text { Diluted treated wastewater } \\
\qquad(\% \mathrm{TW})\end{array}$ & & $168 \mathrm{~kg}$ & $400 \mathrm{~kg}$ & $974 \mathrm{Kg}$ \\
\hline
\end{tabular}

Table 5. Detail of mix design of concrete samples.

\begin{tabular}{cccc}
\hline Parameter & $\begin{array}{c}\text { Control } \\
(\underline{\mathbf{C t r l}})\end{array}$ & $\begin{array}{c}\text { Treated wastewater (TWW), } \\
\text { Concentrated treated wastewater (TW+\%C), } \\
\text { Diluted treated wastewater (\%TW) }\end{array}$ & $\begin{array}{c}\text { Primary } \\
\text { wastewater } \\
\text { (PWW) }\end{array}$ \\
\hline Free water mass & $168 \mathrm{~kg}$ & - & - \\
Wastewater mass & - & $168 \mathrm{~kg}$ & $168 \mathrm{~kg}$ \\
Cement mass & $400 \mathrm{~kg}$ & $400 \mathrm{~kg}$ & $400 \mathrm{~kg}$ \\
Sand mass & $974 \mathrm{Kg}$ & $974 \mathrm{Kg}$ & $974 \mathrm{Kg}$ \\
Fine gravel mass & $185 \mathrm{~kg}$ & $185 \mathrm{~kg}$ & $185 \mathrm{~kg}$ \\
Coarse gravel mass & $576 \mathrm{~kg}$ & $576 \mathrm{~kg}$ & $576 \mathrm{~kg}$ \\
Stone powder & 74 & 74 & 74 \\
\hline
\end{tabular}

\section{Results and Discussion}

\subsection{Slump}

The slump shall be consistent with the placement and consolidation methods, equipment, and site conditions and shall be identified by the contractor and concrete supplier prior to construction. According to achieved results, TWW had less workability than the control sample. Diluted specimens reacted like TWW, which shows existence of the wastewater can affect the workability even in low percentages. The concentrated specimens followed the same way of treated TWW, but TW $+25 \% \mathrm{C}$ had a reduction and stayed in next specimens too. The TWW had 13.3\% lower workability than the Ctrl 
specimen and by $25 \%$ increasing the concentration of treated wastewater $\mathrm{TW}+25 \% \mathrm{C}$, the workability declined $20 \%$ than Ctrl. It blatantly showed that wastewater has a subtractive effect on workability and it is dependent on wastewater concentration. So, it is highly recommended that in the project with high required workability, the additives should be considered to increase the slump, especially while more concentrated wastewaters are used as the water of mix design. No linear relationship was observed in any specimens while their concentration was increased or decreased orderly. The concentrated specimens had more viscous and greasier and it is one of the reasons why concentrated specimens had less workability and it was obvious in PWW sample which had the highest impurities. Figure 1 shows the slump test results.

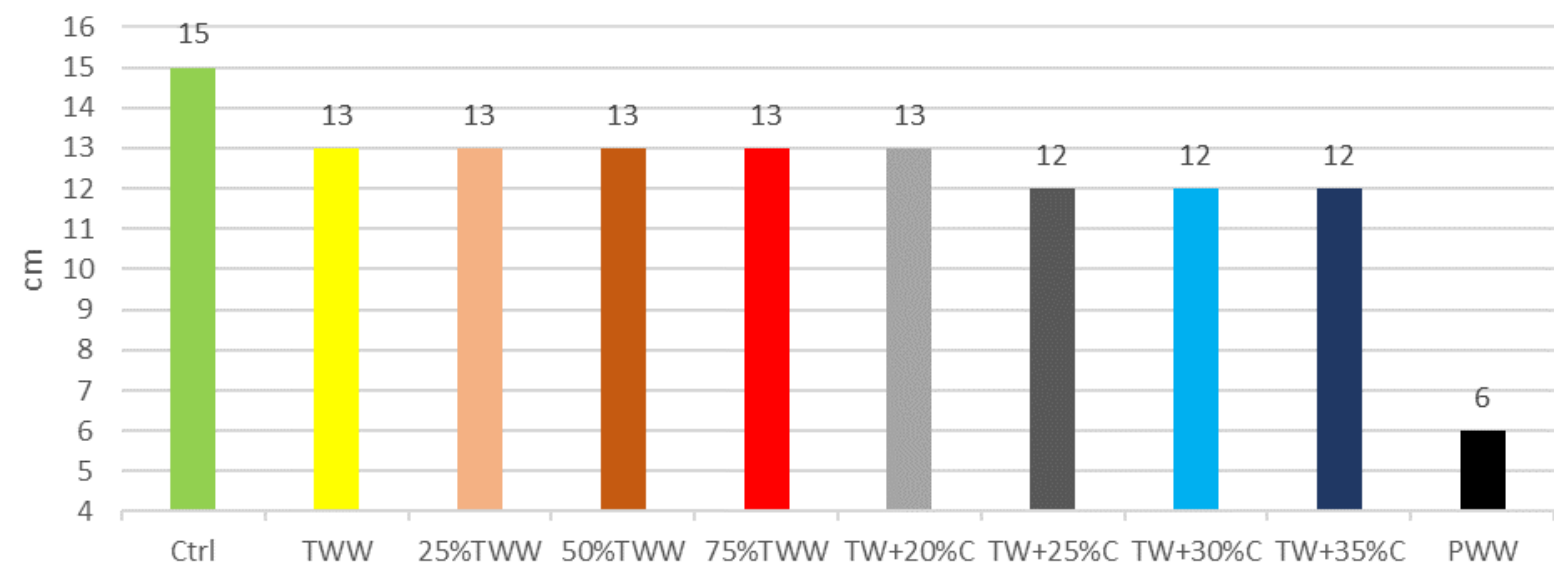

Figure 1. Slump test results

\subsection{Compressive Strength}

The result of compressive strength at different ages days is shown for specimens cured by drinkable water (Figure 2) and cured by treated wastewater (Figure 3). The Ctrl sample had the highest strength in all ages and it substantiated that the best result can be achieved by using drinkable water. TWW had lower strength than Ctrl, but its reduction was insignificant. So, it demonstrated that treated industrial wastewater is applicable for using in concrete. The compressive strength in wastewater specimens was better when the concentration of water for producing and curing were the same. It vividly showed the homogeneity and similarity features between the curing situation and water of the mix design. For instance, at the age of 7, 28, 90, 365 days when TWW and 75\%TW were cured by treated wastewater, they had $0.54 \%, 1.65 \% 1.06 \%, 1.55 \%$ and $2.86 \%, 0 \%, 3.6 \%, 1.06 \%$ more compressive strength than cured by standard water, respectively. Besides, $25 \% \mathrm{TW}$ which its mixed design water was roughly similar to drinkable water had $1.62 \%, 1.1 \%$, $1.6 \%, 1.02 \%$ more compressive strength, when it was cured by standard water in different ages. The concentrated specimens in low ages had better performance when they were cured by treated wastewater but in late ages, they showed better results by drinkable water. The positive effect of curing with treated wastewater for those specimens produced by treated wastewater disappeared by increasing the specimens' concentration and got changed adversely. For example, TW $+35 \% \mathrm{C}$ cured by treated wastewater had $3 \%$, $3.1 \%, 2.4 \%, 2.6 \%$ less compressive strength when it was cured by treated wastewater than was cured by drinkable water. PWW produced by primary wastewater and had the highest impurity, corroborated this result and it had 2.6\%, 5.3\%, 4.5\%, 4.3 less compressive strength when it was cured by treated wastewater. Neither in diluted specimens nor concentrated specimens, linear relationship was observed and non-linear relationship was dominant; however, the concentration of specimens was increased and decreased orderly. 


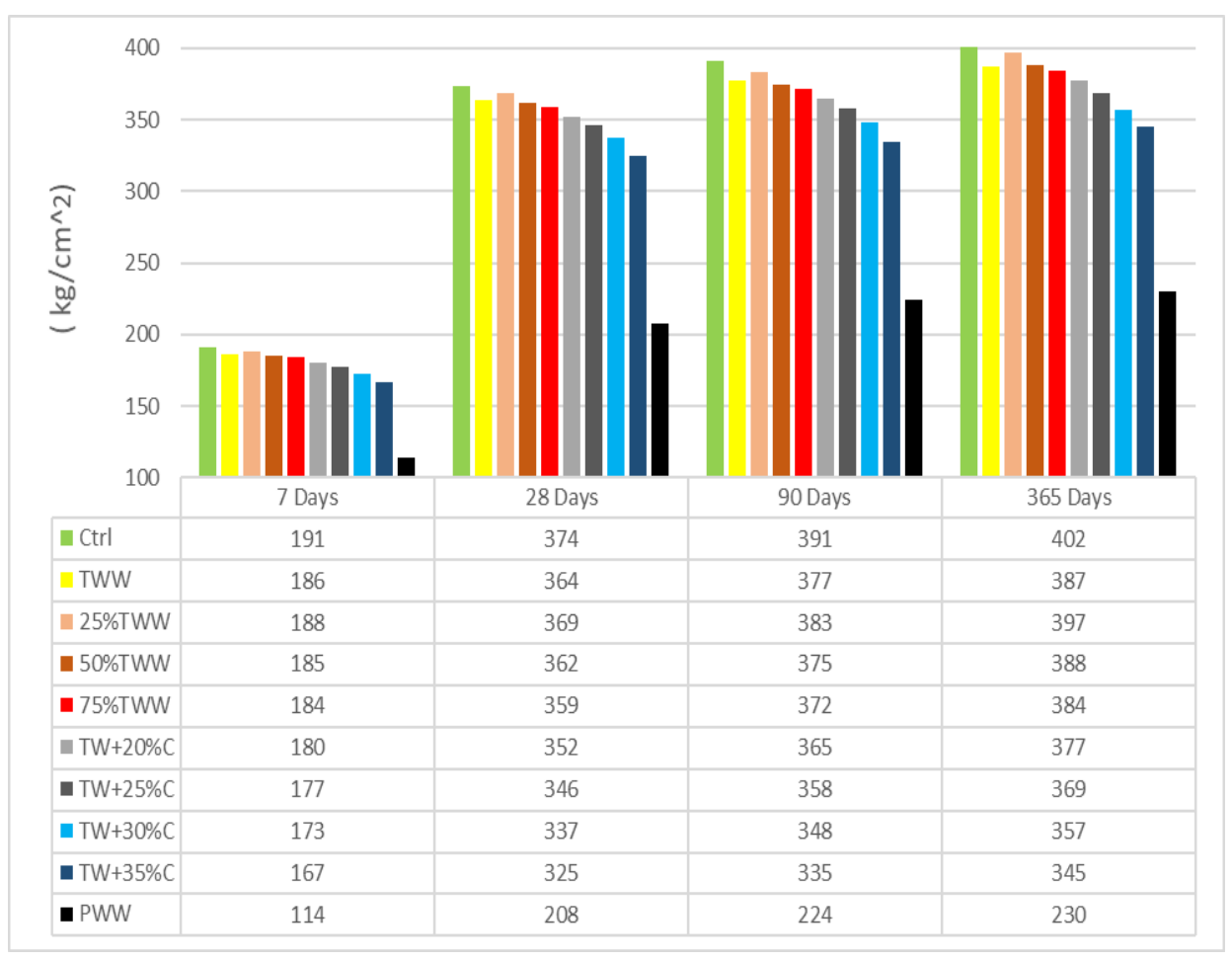

Figure 2. Compressive strength cured by drinkable water $\left(\mathrm{kg} / \mathrm{cm}^{2}\right)$ at $7,28,90$, and 365 days.

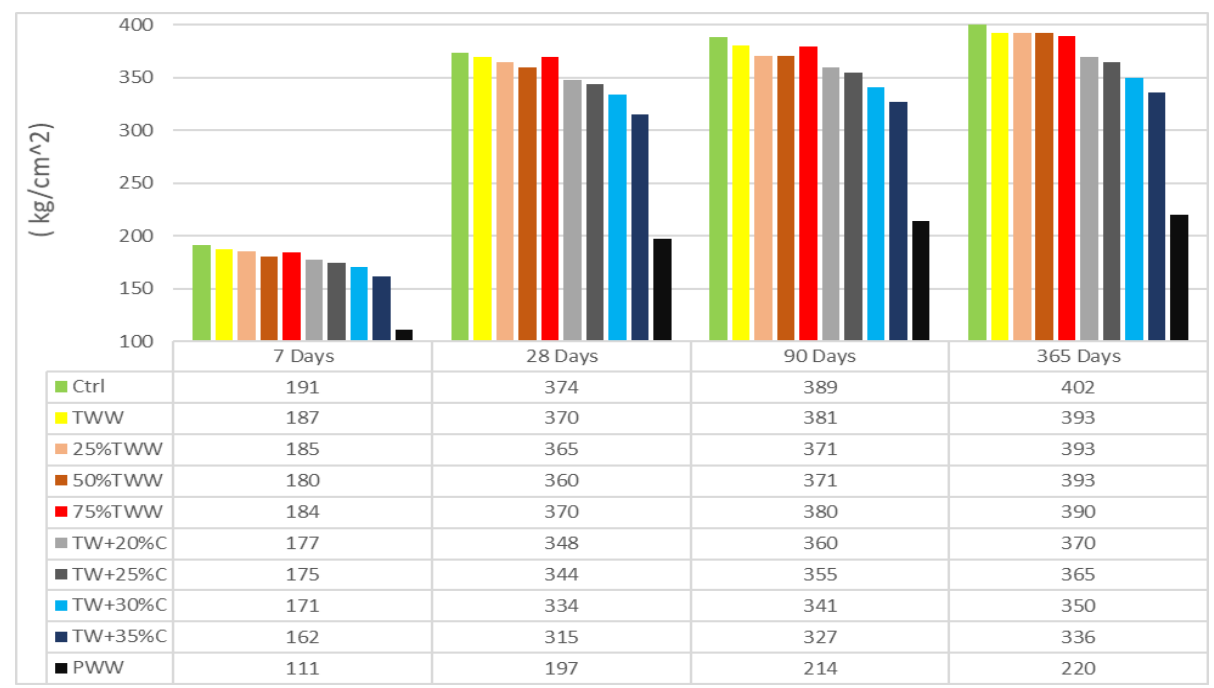

Figure 3. Compressive strength cured by treated wastewater $\left(\mathrm{kg} / \mathrm{cm}^{2}\right)$.

By aging, concentrated specimens had less compressive strength growth than Ctrl sample and by increasing the specimens' concentration the reduction was increasing. One of the most important intentions of this study was to find the impurity and concentration of the wastewater which causes $10 \%$ reduction in compressive strength of concrete in comparison to Ctrl after 28 days. Based on Figures 2 and 3, TW+30\%C cured by drinkable water and treated wastewater at the age of 28 , had $9.9 \%$ and $10.7 \%$ less compressive strength than Ctrl; respectively. It clarified the worst amount of impurity in industrial treated wastewater which can be still applicable [34]. It exhibited the most optimum concentration of wastewater to balance mechanical, durability and physical characteristics. 


\subsection{Electrical resistivity}

The level of permeability of concrete has direct effect on electrical resistivity of specimens. This test indicates specimens' permeability and specifies existing voids and cracks in the concrete structure which has a significant effect on concrete durability [38]. Figures 4 and 5 present electrical resistivity of specimens. at the age of 7, 28, 90, 180 and 365 days.

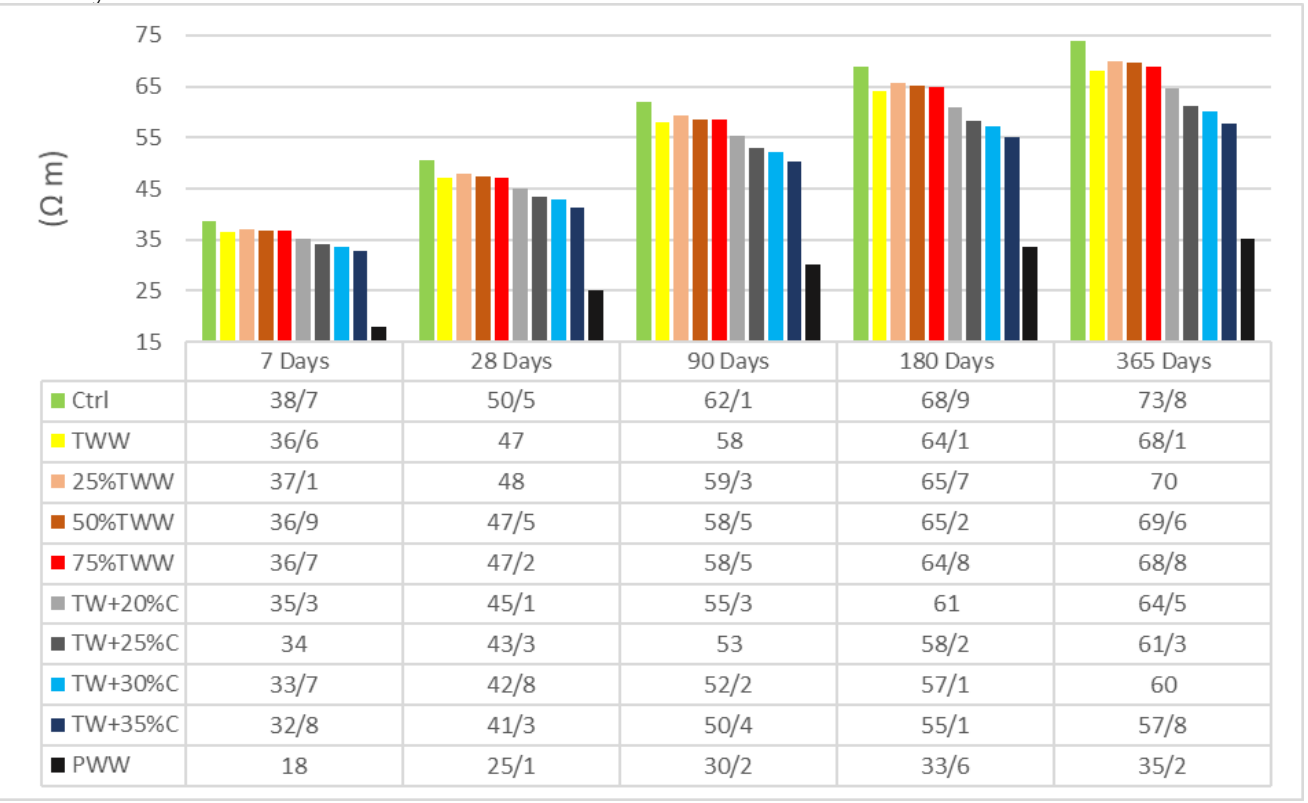

Figure 4. The results of concrete electrical resistivity tests cured by standard water.

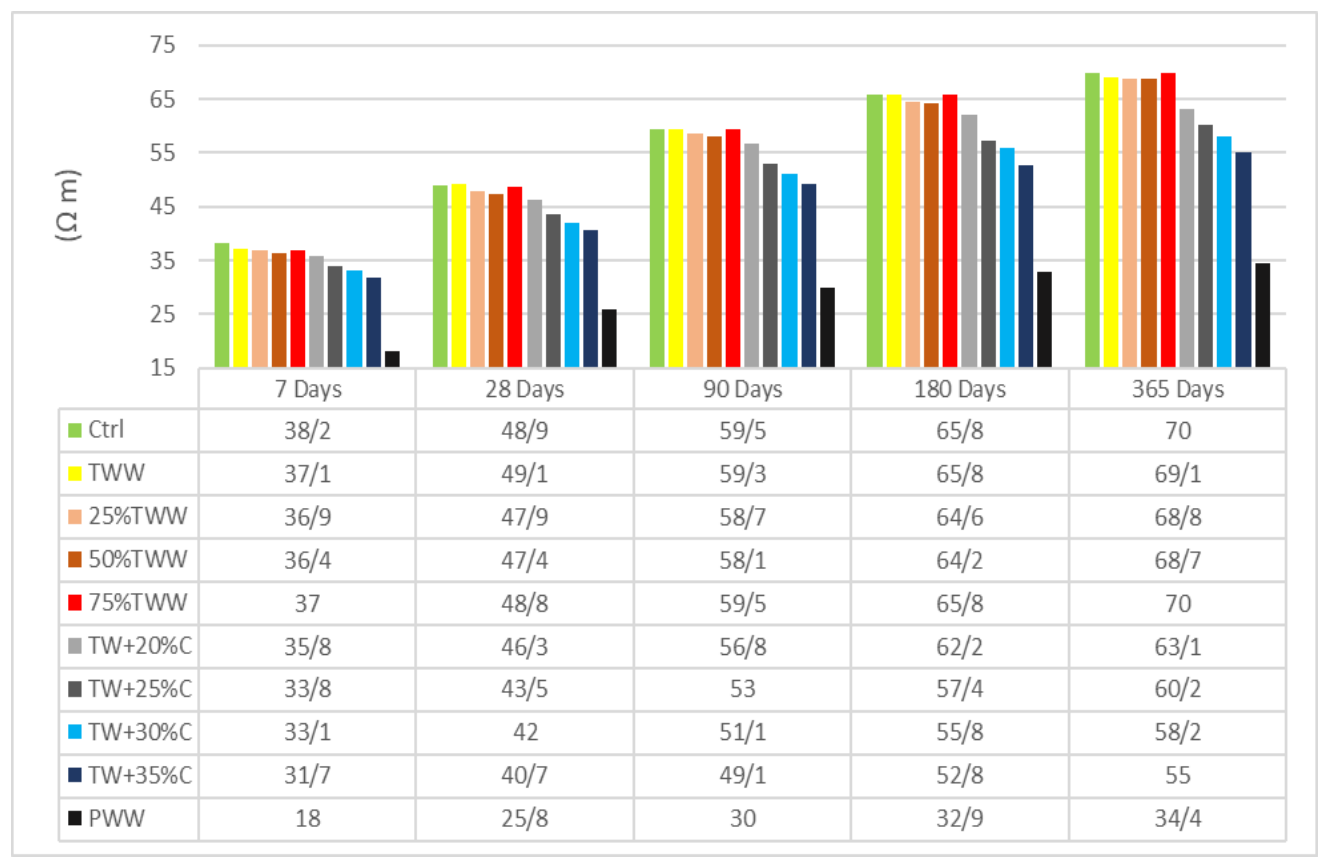

Figure 5. The results of concrete electrical resistivity tests cured by treated wastewater (TWW).

Ctrl sample had better resistance when it was cured by drinkable (standard) water and a reduction was observed when cured by treated wastewater. Also, by concentrating the concentration, electrical homogeneity was decreasing. The diluted specimens' behavior was inclined toward the TWW results not Ctrl, even when insignificant treated wastewater was involved. For example, $25 \% \mathrm{TW}$ which its producing water is $75 \%$ drinkable water, followed the TWW resistance not Ctrl, either cured by drinkable water 
or treated wastewater. It showed that whenever wastewater parameters are involved in the specimens, they could exceedingly influence the concrete structure and they make void and porosity in specimens. So, diluting the concentration has insignificant effect on electrical resistivity enhancement. TWW and specimens with close concentration to TWW, had better resistivity when they were cured by treated wastewater in low ages, however, by aging the positive effect was declining even on them; as if being cured by treated wastewater in long term have caustic effects on the concrete structure and causes more penetration ways. Nevertheless, specimens with a lower concentration at an early age, a resistance growth was observed which again supported the positive effect of homogeneity feature as well as negative effect of being cured by treated wastewater in long term.

At the age of 28 days, $\mathrm{TW}+30 \% \mathrm{C}$ cured by drinkable and treated wastewater had $\% 15$ and \%14 less electrical resistivity than Ctrl sample; respectively. It indicated that using wastewater in concrete has more negative effects on concrete's durability features than strength aspects because it had \%10 reduction in compressive strength test but $\% 15$ in electrical resistivity. Therefore, it is recommended not to use treated wastewater for projects with high touch with caustic material or marine projects.

\subsection{Water Absorption Mass}

For the water absorption test, the specimens are dried in an oven for a specified time and temperature and then placed in a desiccator to cool. Immediately upon cooling the specimens are weighed. The material is then emerged in water at agreed upon conditions, often $23^{\circ} \mathrm{C}$ for 24 hours or until equilibrium. This test was done based on BS1881-122 [27]. Table 6 indicates the results of mass water absorption which has a significant relationship with concrete permeability. The less porous and crack the structure of concrete has, the less possibility exists for moving harmful parameters into the structure of concrete; consequently, the concrete corrosion is less expected. Hence, based on BS1881-122 the allowable water absorption is restricted between $2 \%$ to $5 \%$. In this test except PWW, all other specimens were stood in the allowable limitation after 72 hours, however, $\mathrm{TW}+35 \% \mathrm{C}$ stood at the edge of rejection. This test showed that not only using wastewater increases water absorption, but also the rate of age to age water absorption growth is more than Ctrl which is improper. For instance, Ctrl sample from 1 hour to 72 hours had \%49.5 water absorption growth; but TWW and TW+30\%C had $53.3 \%$, and $63.4 \%$, respectively. The $\mathrm{TW}+30 \% \mathrm{C}$ had $39.5 \%$ more mass water absorption than Ctrl, which acknowledged the exactness of 30 minutes water absorption results. Table 6 shows the mass water absorption.

Table 6. Mass water absorption

\begin{tabular}{ccccc}
\hline & 1 Hour (\%) & 3 Hour (\%) & 24 Hour $\mathbf{( \% )}$ & 72 Hour $\mathbf{( \% )}$ \\
\hline Ctrl & 2.10 & 2.62 & 2.93 & 3.14 \\
TWW & 2.42 & 3.05 & 3.54 & 3.71 \\
$\mathbf{2 5 \% T W}$ & 2.30 & 2.78 & 3.05 & 3.2 \\
$\mathbf{5 0 \% T W}$ & 2.30 & 2.85 & 3.25 & 3.45 \\
$\mathbf{7 5} \%$ TW & 2.34 & 2.94 & 3.38 & 3.52 \\
TW + 20\%C & 2.55 & 3.21 & 3.60 & 3.88 \\
TW + 25\%C & 2.64 & 3.39 & 3.85 & 4.18 \\
TW + 30\%C & 2.68 & 3.48 & 4.00 & 4.38 \\
TW + 35\%C & 2.90 & 3.83 & 4.40 & 4.92 \\
PWW & 8.6 & 11.04 & 12.45 & 13.60 \\
\hline
\end{tabular}

\subsection{Capillary water absorption}

The capillary test evaluates the process of non-saturated concrete water absorption by capillary suction while it is in touch with water. Table 7 shows the results of capillary water absorption at 3,6, 24, and 72 hours. Basically, the more moisture concrete contains, the less capillary water absorption will be measured. The capillary water absorption was 
increasing by using wastewater; even $25 \% \mathrm{TW}$ which contained 75 percent distilled water had \%11.19 more capillary water absorption than Ctrl at 72 hours. It showed that treated wastewater even with low concentration, influences capillarity absorption and subsequently reduces concrete durability. Using wastewater causes bigger and looser capillary pipes which are connected to each other and intensify the concrete corrosion. The more and larger capillary pores a concrete has, the more deleterious substances will go into superficial and interior layers of concrete. For instance, after 72 hours TWW samples had $25.87 \%$ more capillary water absorption growth than (Ctrl); this growth for $\mathrm{TW}+30 \% \mathrm{C}$ was $95.30 \%$.

Table 7. The results of capillary water absorption $\left(\frac{g r}{m m^{2}}\right.$ or $\left.\mathrm{mm}\right)$

\begin{tabular}{ccccc}
\hline Sample & 3 hour (\%) & $\mathbf{6}$ hour (\%) & 24 hour (\%) & 72 hour (\%) \\
\hline CTRL & 1.35 & 1.72 & 2.00 & 2.86 \\
TWW & 1.66 & 2.14 & 2.54 & 3.70 \\
25\%TW & 1.46 & 2.05 & 2.28 & 3.18 \\
50\%TW & 1.53 & 2.12 & 2.40 & 3.38 \\
$75 \%$ TW & 1.57 & 2.08 & 2.40 & 3.44 \\
TW+20\%C & 1.80 & 2.35 & 2.84 & 4.22 \\
TW+25\%C & 1.88 & 2.52 & 3.18 & 4.86 \\
TW+30\%C & 1.94 & 2.62 & 3.40 & 5.22 \\
TW+35\%C & 2.05 & 2.84 & 3.70 & 5.65 \\
PWW & 8.90 & $12 . .88$ & 16.85 & 29.32 \\
\hline
\end{tabular}

Figure 6 indicates the rate of growth during the test period. The wastewater specimens had more capillary water absorption and growth rates than the (Ctrl) sample. For example, from 24 to 72 hours, (TWW) and (TW+30\%C) had $4 \%$ and $10 \%$ more growth than (Ctrl). So, based on Table 8, 9 and 10, it is highly recommended not to utilize wastewater with high concentration as the water of concrete mix design when it is going to be used in caustic environments because of the high possibility of corrosion.

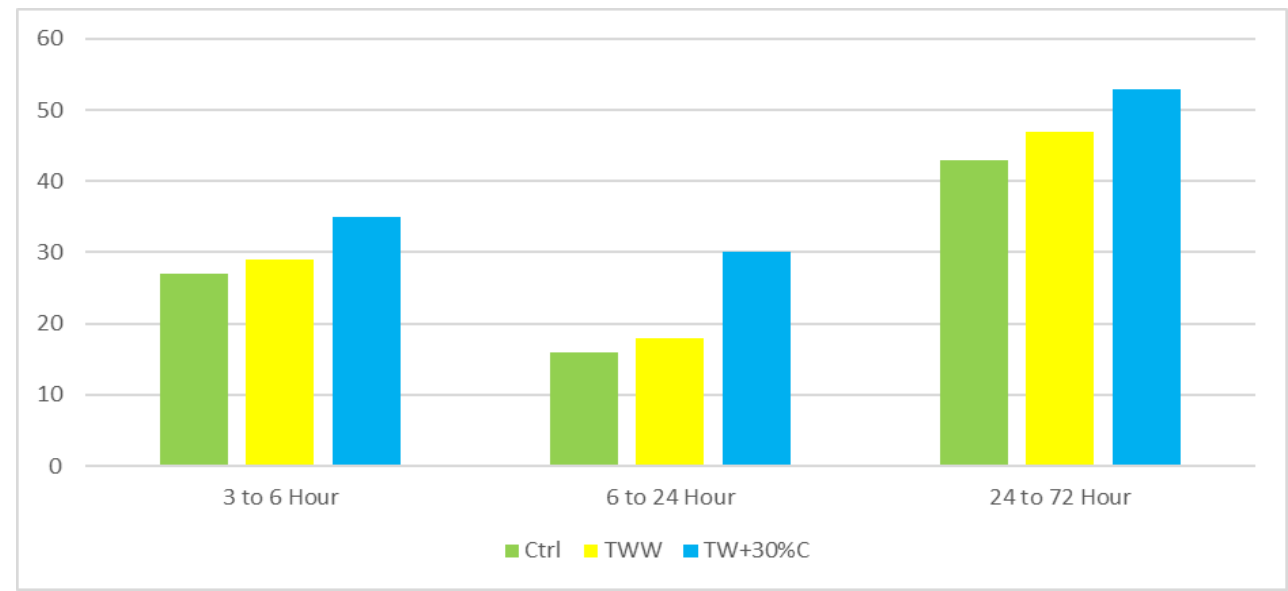

Figure 6. The capillary water absorption growth hour to hour (\%).

\subsection{Tensile strength}

The tensile strength of concrete is a prominent property when it is to be utilized in making prestressed concrete structure, roads and runways. Figures 7 and 8 illustrate the 
results of tensile strength on day of 7 and 28 cured by drinkable water and treated wastewater; respectively. This test illustrated that behavior of specimens in tensile strength test is approximately like compressive strength test but the situation is worse in concentrated specimens. For example, TW $+30 \% \mathrm{C}$ sample cured by drinkable water and treated wastewater at the day of 28 had almost $10 \%$ less compressive strength than Ctrl; nevertheless, in tensile strength it had 19\% less tensile strength. It indicated that Interfacial Transition Zone (ITZ) area is weaker in wastewater specimens and the desire for water absorption is more in this area. Some wastewater parameters like sludge, have spongy features and they reduce available water for hydration reaction, while the water cement ratio is needed more in ITZ region [34]. In addition, some other greasy wastewater like oils cover the aggregates' surface and hamper the proper connection between cement and aggregates in ITZ region [34]. That is why the tensile strength is more affected by increasing the concentration tensile compared to pressive strength. Although, the specimens' concentration was increased and decreased in order, no linear relationship was observed between in diluted or concentrated specimens.

Not only by increasing the concentration tensile strength declined, but also the rate of tensile strength growth was lower than Ctrl sample. For instance, within day of 7 to 28, the Ctrl sample cured by drinkable water and treated wastewater had $85.3 \%$ and $84.4 \%$ growth. But TW $+30 \% \mathrm{C}$ had $78 \%$ and $77 \%$ tensile strength growth, and $\mathrm{TW}+35 \% \mathrm{C}$ had $77 \%, 75 \%$; respectively.

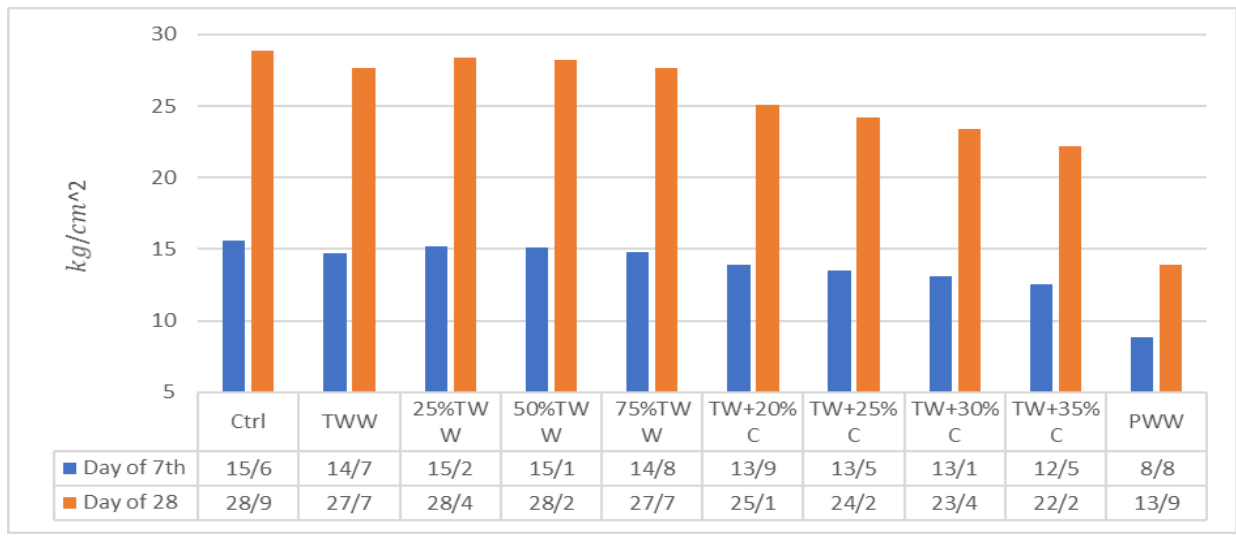

Figure 7. The results of tensile strength cured by drinkable water $\left(\frac{\mathrm{kg}}{\mathrm{cm}^{2}}\right)$.

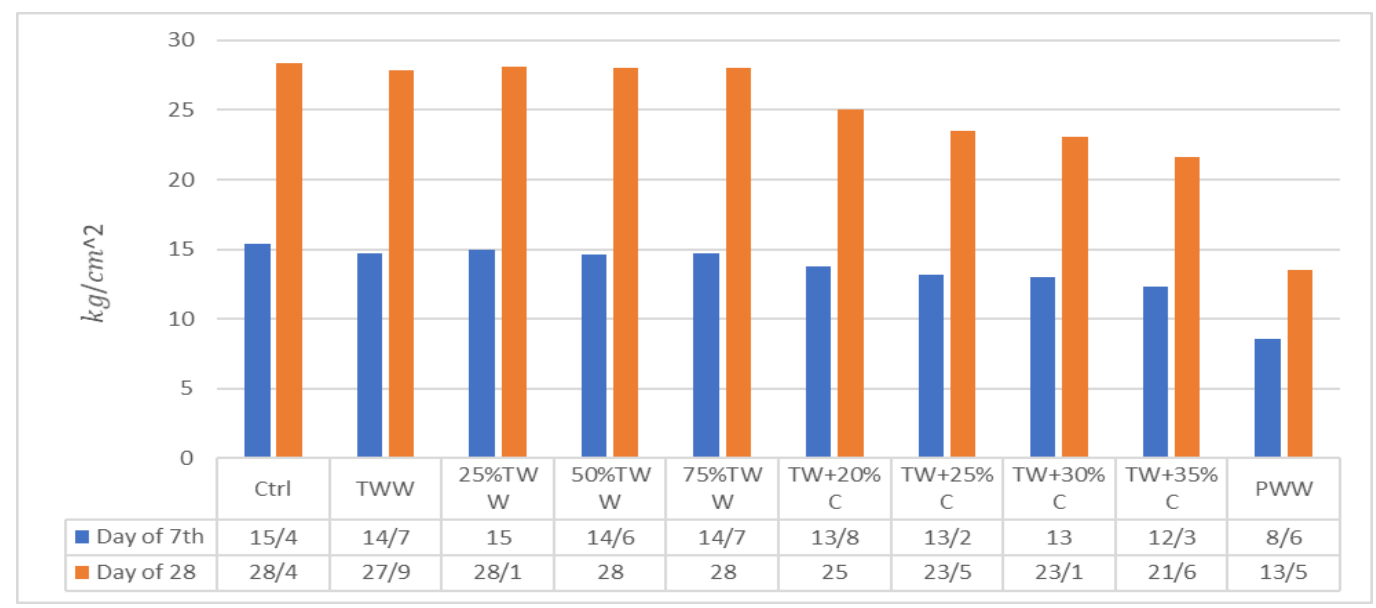

Figure 8. The results of tensile strength cured by treated wastewater $\left(\frac{\mathrm{kg}}{\mathrm{rm}^{2}}\right)$. 


\subsection{Rapid Freezing and Thawing}

Table 8 indicates the compressive strength of specimens at the age of 28 days results and the strength reduction of each cycle due to rapid freezing and thawing test Change in compressive strength: the decline of more than $10 \%$ is the sign of fail. The volume expansion is the first reason for cracking in concrete. This expansion is caused by frozen water inside of concrete. Another reason for cracking is thermal stress. Thermal stresses appear because of repeated freeze-thaw cycles. By increasing the number of fast freeze-thaw cycles, the value of the mechanical property declines.

The pore-size distribution is known as one of the main factors which remarkably affects the freezing and thawing resistance. Generally, existing air bubbles into the concrete are effective to enhance its resistance to disintegration when exposed to cycles of freezing and thawing in a censoriously saturated state, and to decrease the scaling that evolving applications of chemicals for ice removal. Furthermore, air bubbles that are bigger than roughly 3 micrometers give higher resistance to destruction created by freezing and thawing cycles. The recommended bubble distribution is less than $0.2 \mathrm{~mm}$, but by using wastewater instead of drinkable water, the pores become harmful. Also, the free spacing and pore structure might be destroyed and get clogged by TDS and other wastewater's impurities. So, less freezing and thawing resistance is expected. Regarding to the existing more impurities in wastewater, especially total dissolved solid in the used wastewaters, larger and relatively more connected pores are expected. Technically, the air bubbles in the concrete provide solace from the strain originated from the freezing of water in the capillary gaps in the concrete specimens and thus minimize damage to the hardened paste [34].

Results showd that the reduction rate in the Ctrl and TWW samples was almost the same until 100 cycles, but after that TWW demonstrated different behavior and declined more than Ctrl sample. For instance, until 100 cycles in comparison to day of 28 compressive strength, Ctrl and TWW had almost 3\% strength reduction; but in 150 and 200 cycles Ctrl had $4 \%$ and 5\% reduction while TWW had $6 \%$ and $7.6 \%$ compressive strength reduction, respectively. Interestingly, 75\%TW also had the same reaction like TWW and the rate of reduction raised after cycle 100 and no notable difference was observed in $25 \% \mathrm{TW}$, which is close to Ctrl specimen and it showed the negative effect of using wastewater due to making more void in concrete structure. Compare to Ctrl sample, concentrated specimens had more compressive strength reduction in all cycles, and by increasing the concentration and cycles, the rate of reduction was raising.

Table 8. The results of resistance of concrete to rapid freezing and thawing.

\begin{tabular}{|c|c|c|c|c|c|}
\hline Samples & 28-day compressive strength & $\begin{array}{c}50 \text { cycles } \\
\left(\frac{k g}{\mathrm{~cm}^{2}}\right)\end{array}$ & $\begin{array}{c}100 \text { cycles } \\
\left(\frac{\mathrm{kg}}{\mathrm{cm}}\right)\end{array}$ & $\begin{array}{c}150 \text { cycles } \\
\left(\frac{\mathrm{kg}}{\mathrm{cm}^{2}}\right)\end{array}$ & $\begin{array}{c}200 \text { cycles } \\
\left(\frac{\mathrm{kg}}{\mathrm{cm}^{2}}\right)\end{array}$ \\
\hline Ctrl & 374 & 364 & 353 & 339 & 322 \\
\hline TWW & 358 & 348 & 337 & 317 & 293 \\
\hline $25 \%$ tw & 370 & 360 & 349 & 334 & 317 \\
\hline $50 \%$ tw & 361 & 351 & 340 & 326 & 302 \\
\hline $75 \%$ tw & 358 & 348 & 338 & 319 & 297 \\
\hline $\mathrm{tw}+20 \% \mathrm{C}$ & 355 & 342 & 329 & 306 & 280 \\
\hline $\mathrm{tw}+25 \% \mathrm{C}$ & 344 & 330 & 316 & 291 & 265 \\
\hline $\mathrm{tw}+30 \% \mathrm{C}$ & 335 & 320 & 304 & 280 & 253 \\
\hline $\mathrm{tw}+35 \% \mathrm{C}$ & 322 & 305 & 289 & 265 & 239 \\
\hline PWW & 208 & 187 & 172 & 155 & 136 \\
\hline
\end{tabular}


Figure 9 shows the compressive strength reduction due to rapid freezing and thawing which has direct relationship with having more void and porosity in concrete structure. In fact, by having more sulphate, BOD and COD in utilized wastewaters, the availability of air-voids became less with lower spacing which increased the pressure in concrete. Consequently, less freezing and thawing resistance obtained in concentrated specimens. Likewise, the most important factor influencing freezeing and thawing resistance is pore connectivity which means the higher the connectivity of the macropores, the higher the resistance of the concrete. Nevertheless, the existing oil and impurities in wastewater led to losing the connectivity of the pores and freezing and thawing resistance dropped. These differences were more conspicuous after 100 cycles when the pressure reached to the peak.

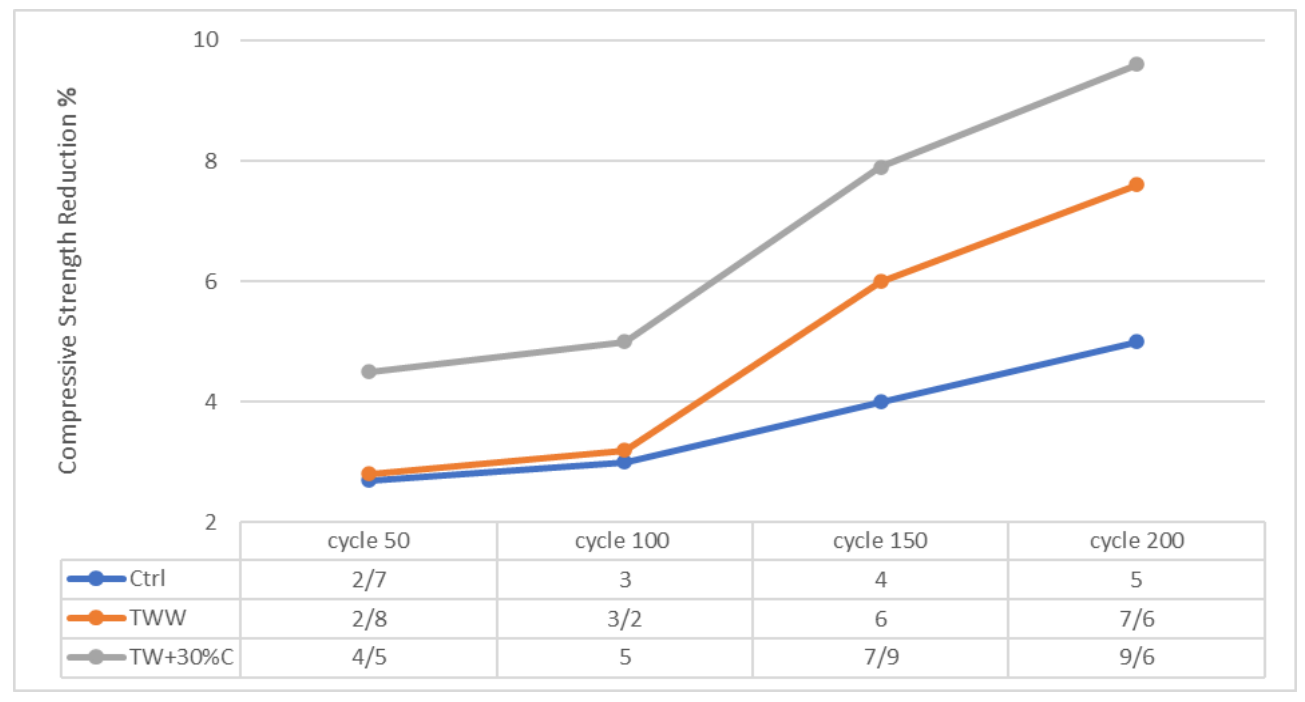

Figure 9. The compressive strength reduction in each rapid freezing and thawing cycle.

Using wastewater causes more void in concrete structure and these specimens can contain water and subsequently more expected in freezing and thawing test. TW+30\%C in 50, 100, 150, and 200 cycles had $12 \%, 13.9 \%, 17.4 \%$, and $21.4 \%$ less compressive strength than Ctrl. Based on achieved results, air voids size-distribution have more prominent effects on the resistance than the air-void spacing. Therefore, based on obtained results, air void structure in air-entrained concretes utilizing a Protected Paste Volume (PPV) parameter is recommended which protects the paste area by air voids to the total paste area.

\subsection{Half-cell potential}

Table 9 illustrates the half-cell potential which is influenced by Chloride ion and internal Alkaline environment of concrete. Basically, increasing the wastewater concentration caused more reduction in reinforcement corrosion potential. In the other word, by aging the specimens and increasing the concentration of used wastewater as the water of mixture design, the possibility of corrosion became more [34]. For instance, the corrosion in TW $+30 \% \mathrm{C}$ and PWW was started after 24 and 8 days; it is clearly because of wastewater parameters. Basically, half-cell potential decreased when chloride content and sulphate content increased in the wastewaters' concentration. In fact, those specimens with higher compressive strength demonstrated better half-cell potential. Likewise, the extent of corrosion escalated with the reduction of the half-cell potential. According to the voltage, corrosion was conspicuous when half-cell potential was lower than -450 $\mathrm{mV}$ in dry condition. In addition, using more concentrated wastewater not only decreased the level of half-cell potential, but it also negatively affected the level of corrosion and the age of corrosion start. For instance, PWW which had the highest chloride and sulphate in comparison to other specimens, the age of corrosion was almost four times sooner than the Ctrl and even TWW. Clearly, the level of corrosion speeded up with the decline of the half-cell potential. 
Table 9. The start age of armature corrosion

\begin{tabular}{cc}
\hline Sample & Age of corrosion start (day) \\
\hline Ctrl & 32 \\
TWW & 27 \\
$25 \%$ tw & 30 \\
$50 \%$ tw & 28 \\
$75 \%$ tw & 28 \\
TW+20\%C & 24 \\
TW+25\%C & 24 \\
TW+30\%C & 24 \\
TW $+35 \% C$ & 22 \\
PWW & 8 \\
\hline
\end{tabular}

\subsection{Statistical Analysis}

In scientific research, researchers seek to present results as quite practical and, of course, as easy as possible. One of the most important ways that other researchers can make practical use of research is to provide mathematical models for use in future experiments and research [39]. In this study, after completing the laboratory phase, the authors collected laboratory data to examine the data's relationship. Data were analyzed using SPSS statistical analysis software. In this statistical analysis, some input parameters including TDS, TSS, EC, Detergent, Sulfate, Chromium, and Cadmium to predict output parameters including Compressive Strength, Electrical Resistivity, Tensile Strength, Rapid Freezing and Thawing, Water Absorption in 30 min, Water Absorption Mass 72 hours, and Capillary Water Absorption 72 HOUR were used. The statistical indicators of all parameters are shown in Table 10.

Table 10. Statistical characteristics of variables.

\begin{tabular}{cccccccc}
\hline Variables & Mean & Maximum & Minimum & Kurtosis & Skewness & Variance & Std. Deviation \\
\hline TDS & 1879.2500 & 2431.00 & 1014.00 & -1.249 & -0.522 & 272887.933 & 522.38677 \\
EC & 3935.5000 & 3959.00 & 3880.00 & -0.461 & -1.251 & 1064.000 & 32.61901 \\
TSS & 25.6250 & 38.00 & 10.00 & -1.607 & -0.306 & 108.517 & 10.41713 \\
Detergent & 1.2587 & 1.80 & 0.70 & -1.494 & -0.206 & 0.152 & 0.39002 \\
Sulfate & 77.0000 & 101.00 & 36.00 & -1.169 & -0.680 & 596.267 & 24.41857 \\
Chromium & 0.8400 & 0.99 & 0.50 & 0.553 & -1.242 & 0.026 & 0.16199 \\
Cadmium & 0.7463 & 0.90 & 0.50 & 0.386 & -0.854 & 0.015 & 0.12099 \\
Compressive Strength & 351.2500 & 370.00 & 315.00 & -0.221 & -0.784 & 281.133 & 16.76703 \\
Electrical Resistivity & 45.4938 & 49.10 & 40.70 & -1.340 & -0.439 & 7.898 & 2.81033 \\
Tensile Strength & 25.7875 & 28.40 & 21.60 & -1.625 & -0.346 & 6.276 & 2.50516 \\
Rapid Freezing and Thawing & 350.3750 & 370.00 & 322.00 & 0.076 & -0.842 & 245.411 & 15.66559 \\
Water Absorption in 30 mins (\%) & 1.9137 & 2.30 & 1.72 & -0.829 & 0.826 & 0.050 & 0.22328 \\
Water Absorption Mass 72 hours (\%) & 3.9050 & 4.92 & 3.20 & -0.031 & 0.708 & 0.317 & 0.56346 \\
Capillary Water Absorption 72 hours (\%) & 4.2063 & 5.65 & 3.18 & -1.504 & 0.491 & 0.874 & 0.93496 \\
\hline
\end{tabular}

In the next step, the normality of the data should be checked. The normality of the data is generally determined by examining the Skewness and Kurtosis coefficients [40-42]. Achieving a situation where data distribution is perfectly normal is practically very rare, so in scientific texts, data is normal when the coefficients of Kurtosis and skewness are in the range of -2 to 2 [43]. According to the coefficients of Kurtosis and skewness in Table 19, all variables have a normal distribution. Once the normality of data is determined, it is time to determine the correlation coefficient between the variables. For normal data, the Pearson correlation test is used. Table 11 presents the results of the Pearson correlation test. 
Table 11. Pearson correlation coefficients between inputs and outputs in this study.

\begin{tabular}{|c|c|c|c|c|c|c|c|c|}
\hline & & \multicolumn{7}{|c|}{ Inputs } \\
\hline & & $\underset{\omega}{\exists}$ & $\stackrel{\text { Tr }}{\circ}$ & W & 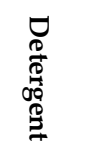 & 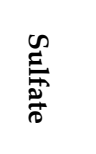 & $\begin{array}{l}\text { 尺े } \\
\text { : } \\
\text { : } \\
\text { : }\end{array}$ & 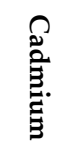 \\
\hline \multirow{7}{*}{$\begin{array}{l}\frac{n}{2} \\
\frac{2}{2} \\
\frac{2}{2}\end{array}$} & Compressive Strength & -0.793 & -0.525 & -0.834 & -0.85 & -0.747 & -0.678 & -0.831 \\
\hline & Electrical Resistivity & -0.81 & -0.536 & -0.858 & -0.856 & -0.77 & -0.688 & -0.817 \\
\hline & Tensile Strength & -0.898 & -0.661 & -0.933 & -0.934 & -0.868 & -0.777 & -0.874 \\
\hline & Rapid Freezing and Thawing & -0.853 & -0.658 & -0.879 & -0.891 & -0.819 & -0.796 & -0.889 \\
\hline & Water Absorption in 30 mins & 0.842 & 0.602 & 0.888 & 0.896 & 0.807 & 0.728 & 0.832 \\
\hline & Water Absorption Mass 72 Hour & 0.896 & 0.697 & 0.927 & 0.942 & 0.869 & 0.831 & 0.902 \\
\hline & Capillary Water Absorption & 0.906 & 0.673 & 0.942 & 0.942 & 0.876 & 0.807 & 0.886 \\
\hline
\end{tabular}

Once the correlation coefficients have been determined it is time to determine the estimation models for research outputs. Multivariate linear regression is used for this purpose. The general form of multivariate linear regression is as follows [44-46]:

$$
\mathrm{Y}=\mathrm{a}_{0}+\mathrm{a}_{1} \mathrm{X}_{1}+\mathrm{a}_{2} \mathrm{X}_{2}+\mathrm{a}_{3} \mathrm{X}_{3}+\ldots,
$$

where, $\mathrm{Y}$ is dependent variable (output of model), $\mathrm{X} \mathrm{i}$ are independent variables (inputs of model), and ai are regression coefficients of model. The models obtained from the analysis performed with SPSS software are presented in Table 12. To measure the accuracy of the models, two criteria R2 and standard error were used.

Table 12. Prediction models for determining characteristics of concrete.

\begin{tabular}{|c|c|c|}
\hline Equations & $\mathbf{R}^{2}$ & $\begin{array}{l}\text { Std. } \\
\text { Error }\end{array}$ \\
\hline $\begin{array}{c}\text { Compressive Strength }=2504.102-0.017 \mathrm{TDS}-4.693 \mathrm{TSS}-24.11 \text { Detergent }+2.869 \text { Sulfate } \\
+93.896 \mathrm{Chromium}-134.054 \text { Cadmium }-0.551 \mathrm{EC}\end{array}$ & 0.964 & 4.37321 \\
\hline Electrical Resistivity $=467.794-1.426 \mathrm{TSS}+7.087$ Detergent +0.522 Sulfate +15.7 Chromium -17.614 Cadmium $-0.110 \mathrm{EC}$ & 0.960 & 0.76933 \\
\hline $\begin{array}{c}\text { Tensile Strength }=280.918+0.001 \mathrm{TDS}-0.066 \mathrm{EC}-0.758 \mathrm{TSS}+2.536 \text { Detergent }+0.197 \mathrm{Sulfate}+19.169 \text { Chromium }-17.064 \text { Cadmium } \\
\text { Rapid Freezing and Thawing }=3634.478-0.021 \mathrm{TDS}-0.847 \mathrm{EC}-7.396 \mathrm{TSS}-1.118 \mathrm{Detergent} \\
+4.532 \text { Sulfate }-24.176 \mathrm{Chromium}-63.520 \text { Cadmium }\end{array}$ & 0.994 & 0.25981 \\
\hline $\begin{array}{l}\text { Water Absorption in } 30 \mathrm{~min}=0.0006092 \mathrm{TDS}+0.011 \mathrm{EC}+0.112 \mathrm{TSS}-0.19 \mathrm{Detergent} \\
-0.051 \text { Sulfate }-0.739 \text { Chromium }+0.945 \mathrm{Cadmium}-39.212\end{array}$ & 0.998 & 0.0002 \\
\hline $\begin{array}{l}\text { Water Absorption Mass } 72 \text { hours }=0.02 \mathrm{EC}+0.178 \mathrm{TSS}+1.037 \text { Detergent }-0.104 \text { Sulfate } \\
\qquad+0.515 \text { Chromium }+1.866 \text { Cadmium }-74.792\end{array}$ & 0.997 & 0.0005 \\
\hline $\begin{array}{l}\text { Capillary Water Absorption } 72 \text { HOUR }=0.001 \mathrm{TDS}+0.032 \mathrm{EC}+0.389 \mathrm{TSS}-1.269 \text { Detergent }-0.161 \text { Sulfate } \\
\qquad-1.902 \text { Chromium }+2.821 \text { Cadmium }-117.984\end{array}$ & 0.999 & 0.0001 \\
\hline
\end{tabular}

The equations presented in Table 12 are very accurate, but they include an important point. These equations are constructed based on laboratory data of this study. If the number of laboratory data is increased, the coefficients of the models will may change slightly. Therefore, the authors recommend that other researchers, before applying these equations, first calibrate the models for their project or research conditions and then use them.

In sum, the achieved results were commensurate with other tests with data integrity, and no significant contradiction was observed. Negative impact of the wastewater was conspicuous in durability results and curing with wastewater is not recommended. This research indicated that using industrial wastewater could decrease the quality of pro- 
duced concrete according to its concentration, but based on the results, a proper understanding of using different concentration was presented which helps reaching the economy level of refinement in industrial towns for using their wastewater in the concrete.

\section{Conclusions}

In this paper, ten groups of concrete specimens with different industrial wastewater concentration were produced and cured by drinkable water and treated wastewater separately according to the tests and standards. Using wastewater as water of mix design reduces the strength and durability but TWW can be good and acceptable replacement for the water of mix design and had insignificant strength and durability reduction on concrete in all tests. By concentrating the treated wastewater properties up to $30 \%$ in $(\mathrm{TW}+30 \% \mathrm{C})$ specimen, the compressive strength declined almost $10 \%$ after 28 days which showed the optimum level of concentration for industrial town's refinement. However, concentrating had more adverse effects on durability tests which showed using wastewater causes more negative effects on durability than strength features of concrete. PWW did not have acceptable behavior in any tests, and it was rejected. Although in concentrated and diluted specimens the percentage of wastewater was increased or decreased orderly, no linear relationship in strength and durability tests was observed. Ctrl specimens showed better strength and durability when they were cured by drinkable water which proved homogeneity and similarity features, but wastewater specimens showed better strength and durability when they were cured by wastewater only in low ages, whereas the good effect disappeared in late ages; as if being in touch with treated wastewater for curing damages the specimens and causes corrosion. All of the specimens had less growth in terms of strength and durability when they were cured by treated wastewater in comparison to be cured by drinkable water. Using wastewater reduced the electrical resistivity and increased water absorption of and diluting the treated wastewater could not correct the negative effects on concrete durability; diluted specimens' results were closer to TWW not Ctrl and by increasing the concentration negative effects were more noticeable. In half-cell potential test, using wastewater insignificantly damaged the reinforcement, but specimens with more concentrated wastewater started to get corrosion faster. By concentrating the wastewater, the Freezing-Thawing properties got adversly affected in terms of air content, pore structure and air voids distribution. The specimens' appearances had insignificant differences except for PWW, which had more discontinuity and distinguishable lack of hydration, however, by increasing the concentration, uneven and small cracks on exterior layers were observed. Using wastewater increased water absorption and decreased workability. Therefore, it is highly recommended not to be used in those projects with caustic materials, exposed surface, or when high slump is needed.

Author Contributions: Conceptualization, E.N., D.M.S. and N.K.; methodology, E.N. and D.M.S.; software, N.K; validation, N.K. and A.M.; formal analysis, D.M.S. and N.K.; investigation, E.N.; resources, E.N. and D.M.S.; data curation, E.N. and D.M.S.; writing-original draft preparation, E.N. and D.M.S.; writing - review and editing, N.K.; visualization, A.M.; supervision, D.M.S. and N.K.; project administration, A.M.; funding acquisition, A.M. All authors have read and agreed to the published version of the manuscript.

Funding: This research received no external funding.

Institutional Review Board Statement: Not applicable.

Informed Consent Statement: Not applicable.

Data Availability Statement: not applicable.

Conflicts of Interest: The authors declare no conflict of interest.

\section{References}

1. Sharbatdar, M.K., Abbasi, M., Fakharian, P., Improving the Properties of Self-compacted Concrete with Using Combined 
Silica Fume and Metakaolin. Periodica Polytechnica Civil Engineering, 2020.

2. Naderpour, H., E. Noormohammadi, and P. Fakharian, Prediction of Punching Shear Capacity of RC Slabs using Support Vector Machine. Concrete Research, 2017. 10(2): p. 95-107.

3. Gandomi, A.H., et al., An empirical model for shear capacity of RC deep beams using genetic-simulated annealing. Archives of Civil and Mechanical Engineering, 2013. 13(3): p. 354-369.

4. Gandomi, A.H., et al., Linear genetic programming for shear strength prediction of reinforced concrete beams without stirrups. Applied Soft Computing, 2014. 19: p. 112-120.

5. Guest, J. S., Skerlos, S. J., Barnard, J. L., Beck, M. B., Daigger, G. T., Hilger, H., Jackson, S. J., Karvazy, K., Kelly, Van Loosrecht, M. C. M., Yeh, N. G. A new planning and design paradigm to achieve sustainable resource recovery from wastewater. Environmental Science \& Technology, 2009. Vol. 43, No. 16, pp. 30-72. Doi: 10.1021/es9010515

6. González, O., Bayarri, B., Acena, J., Pérez, S. and Barceló, D. Treatment technologies for wastewater reuse: Fate of contaminants of emerging concern., Advanced Treatment Technologies for Urban Wastewater Reuse: The Handbook of Environmental Chemistry, 2016. Vol. 45, pp. 5-46. Doi: 10.1007/698_2015_363.

7. Gerlach, E. and Franceys, R. Regulating water services for all in developing economies. World Development, 2010. Vol. 38, No. 9, pp. 1229-1240.

8. Asanoa T, Cotruvob JA. Groundwater recharge with reclaimed municipal wastewater: Health and regulatory considerations. J Water Res. 2004;38: 1941-1951.

9. Naderpour, H., A.H. Rafiean, and P. Fakharian, Compressive strength prediction of environmentally friendly concrete using artificial neural networks. Journal of Building Engineering, 2018. 16: p. 213-219.

10. Molinos-Senante, M., Hernández-Sancho, F. and Sala-Garrido, R. Cost-benefit analysis of water-reuse projects for environmental purposes: A case study for Spanish wastewater treatment plants. Journal of Environmental Management, 2011. Vol. 92, No. 12, pp. 3091-3097.

11. Hanjra, M. A., Blackwell, J., Carr, G., Zhang, F. and Jackson, T. M. Wastewater irrigation and environmental health: Implications for water governance and public policy. International Journal of Hygiene and Environmental Health, 2012. Vol. 215, No.3, pp. $255-269$. Doi: 10.1016/j.ijheh.2011.10.003

12. The United Nation Website , 2017 UN World Water Development Report, Wastewater: The Untapped Resource (UNESCO WWAP) https://www.unwater.org/publications/world-water-development-report-2017/, (assessed on 22 ${ }^{\text {nd }}$ March, 2017); ISBN 978-92-3-100201-4

13. Al-Ghusain, Terro, M. and I. Mechanical properties of concrete made with treated wastewater at ambient and elevated temperatures. Kuwait Journal of Science and Engineering, 2003. 30(1): p. 214-244.

14. Shekarchi, Mohammad, M. Yazdian, Mehrdadi, Naser, Use of biologically treated domestic wastewater in concrete, Kuw. Jour. of Sci. and Eng., (2009) $97-111$.

15. G. Asadollahfardi , M. Asadi, J. Hamidreza, A. Moradi , R. Asadollahfardi, Experimental and statistical studies of using wash water from ready-mix concrete trucks and a batching plant in the production of fresh concrete , (2015), 305-314. DOI: 10.1016/j.conbuildmat.2015.08.053

16. Asadollahfardi G, Delnavaz M, Rashnoiee V, Gonabadi N. Use of treated domestic wastewater before chlorination to produce and cure concrete. J Constr Build Mater. 2016; 105:253-261. DOI: 10.1016/j.conbuildmat.2015.12.039

17. APHA (2012) Standard Methods for the Examination of Water and Waste Water. 22nd Edition, American Public Health Association, American Water Works Association, Water Environment Federation. ISBN: 9780875530130

18. BS EN 1008, Mixing water for concrete. Specification for sampling, testing and assessing the suitability of water, including water recovered from processes in the concrete industry, as mixing water for concrete. British Standards Institution. ISBN 0 58040141 3; July 24, 2002

19. ASTM C150-04, Standard Specification for Portland Cement. 2004: ASTM International, West Conshohocken, PA. DOI: 10.1520/C0150-04 
20. ASTM C188-15, Standard Test Method for Density of Hydraulic Cement 2015. ASTM International, West Conshohocken, PA. DOI: $10.1520 / \mathrm{C} 0188-15$

21. ASTM C136 / C136M-19, Standard Test Method for Sieve Analysis of Fine and Coarse Aggregates 2019: ASTM International, West Conshohocken, PA. DOI: 10.1520/C0136_C0136M-19 ASTM C33 / C33M-18, Standard Specification for Concrete Aggregates. 2018: ASTM International, West Conshohocken, PA. DOI: 10.1520/C0033M-18

ASTM C191-19, Standard Test Methods for Time of Setting of Hydraulic Cement by Vicat Needle. 2019: ASTM International, West Conshohocken, PA. DOI: 10.1520/C0191-19

24. ASTM C143 / C143M-15a, Standard Test Method for Slump of Hydraulic-Cement Concrete. 2015: ASTM International, West Conshohocken, PA. DOI: 10.1520/C0143_C0143M-20

25. BS 1881-116, Method for determination of compressive strength of concrete cubes. 1983, British Standards Institution. Revision: 83rd Edition, July 29, 1983

26. ASTM C496 / C496M-17, Standard Test Method for Splitting Tensile Strength of Cylindrical Concrete Specimens. 2017: ASTM International, West Conshohocken, PA. DOI: 10.1520/C0496_C0496M-17

27. BS 1881-122:2011, Testing concrete. Method for determination of water absorption. 2011, British Standards Institution. 11th Edition, July 31, 2011

28. FM 5-578, Florida Method of Test for Concrete Resistivity as an Electrical Indicator of its Permeability Florida a Method of Test for Concrete Resistivity as an Electrical Indicator of its Permeability Designation, F.D.o. Transportation, Editor. 2004.

29. ASTM C1585 -13, Standard Test Method for Measurement Rate of Absorption of Water by Hydraulic-Cement Concretes. 2013: ASTM International, West Conshohocken, PA. DOI: 10.1520/C1585-13

30. ASTM C666 / C666M-15, Standard Test Method for Resistance of Concrete to Rapid Freezing and Thawing 2015: ASTM International, West Conshohocken, PA. DOI: 10.1520/C0666_C0666M-15

31. ASTM C876-91(1999), Standard Test Method for Half-Cell Potentials of Uncoated Reinforcing Steel in Concrete (Withdrawn 2008). 1999: ASTM International, West Conshohocken, PA. DOI: 10.1520/C0876-91R99

ASTM C642-13, Standard Test Method for Density, Absorption, and Voids in Hardened Concrete, ASTM International, West Conshohocken, PA, 2013. DOI: 10.1520/C0642-13

33. ASTM C231 / C231M-17a, Standard Test Method for Air Content of Freshly Mixed Concrete by the Pressure Method, ASTM International, West Conshohocken, PA, 2017, DOI: 10.1520/C0231_C0231M-17A

34. Khushboo Meena. Salamabanu Luhar. "Effect of wastewater on properties of concrete. Journal of Building Engineering; ELSEVIER. Volume. 21. Jan 2019: P106-112, https://doi.org/10.1016/j.jobe.2018.10.003

35. Graham, J.R., et al., Erosion of concrete in hydraulic structures. ACI Materials Journal, 1987. 84(2): p. $136-156$.

36. ASTM C305-14, Standard Practice for Mechanical Mixing of Hydraulic Cement Pastes and Mortars of Plastic Consistency. 2014: ASTM International, West Conshohocken, PA. DOI: 10.1520/C0305-20

37. ASTM C31 / C31M-19a, Standard Practice for making and Curing Test Specimens in the Field. 2019: ASTM International, West Conshohocken, PA. DOI: 10.1520/C0031_C0031M-19A

38. Medeiros-Junior, Ronaldo A., and Maryangela G. Lima. “Electrical Resistivity of Unsaturated Concrete Using Different Types of Cement." Construction and Building Materials; 2016. doi:10.1016.; Page 24-85

39. Danial Mohammadzadeh S. Seyed-Farzan Kazemi. Amir Mosavi. Ehsan Nasseralshariati. Joseph H. M. Tah. Prediction of Compression Index of Fine-Grained Soils Using a Gene Expression Programming Model. Journal of Infrastructures MDPI 2019. Volume 4 issue 2: p. 3-9.

40. Cembrowski, G.S., et al., Statistical analysis of method comparison data: testing normality. American journal of clinical pathology, 1979. 72(1): p. 21-26.

41. Ghasemi, A. and S. Zahediasl, Normality tests for statistical analysis: a guide for non-statisticians. International journal of endocrinology and metabolism, 2012. 10(2): p. 486. 
42. Thode, H.C., Testing for normality. Vol. 164. 2002: CRC press.

43. Nabipour, N., et al., Comparative Analysis of Machine Learning Models for Prediction of Remaining Service Life of Flexible Pavement. Mathematics, 2019. 7(12): p. 1198.

44. Khademi, F., et al., Multiple linear regression, artificial neural network, and fuzzy logic prediction of 28 days compressive strength of concrete. Frontiers of Structural and Civil Engineering, 2017. 11(1): p. 90-99.

45. Chakraborty, A. and D. Goswami, Prediction of slope stability using multiple linear regression (MLR) and artificial neural network (ANN). Arabian Journal of Geosciences, 2017. 10(17): p. 385.

46. Falade, F. and T. Iqbal, Compressive strength Prediction recycled aggregate incorporated concrete using adaptive neuro-fuzzy system and multiple linear regression. International Journal of Civil, Environmental and Agricultural Engineering, 2019. 1(1): p. 19-24. 